\title{
Aplikasi Pendeteksi Cyberbullying Terhadap Komentar Postingan Media Sosial Instagram dengan Metode Nä̈ve Bayes Classifier Berbasis Website
}

\author{
Alfan Syahada Hutagalunga1, Arif Bijaksana Putra Negara ${ }^{\text {a2 }}$, Enda Esyudha Pratama ${ }^{\text {a3 }}$ \\ aProgram Studi Informatika, Fakultas Teknik, Universitas Tanjungpura \\ Jl. Prof. Dr. H. Hadari Nawawi, Pontianak 78124 \\ ${ }^{1}$ alfanshestudent.untan.ac.id \\ ${ }^{2}$ arifbpneinformatika.untan.ac.id \\ ${ }^{3}$ endalinformatika.untan.ac.id
}

\begin{abstract}
Abstrak
Berdasarkan survey data perusahaan analis Sosial Media Marketing yang berbasis di Warsawa, Polandia, NapoleonCat mencatat jumlah pengguna Instagram di Indonesia tahun 2019 mencapai 61.610.000. Instagram memungkinkan penggunanya untuk berbagi momen lewat foto dan video. Instagram juga memiliki fitur untuk mengomentari postingan. Namun dengan adanya fitur tersebut dapat memberikan dampak yang positif dan negatif bagi masyarakat. Salah satu dampak negatifnya adalah cyberbullying. Pada kenyataannya sosial media instagram tidak dapat menyaring komentar sentimen negatif yang mengandung unsur cyberbullying. Dampak dari tindakan cyberbullying dapat mengakibatkan depresi berat hingga bunuh diri. Karenanya, aplikasi pendeteksi cyberbullying di Instagram adalah solusi untuk menemukan komentar yang mengandung kata atau kalimat negatif. Aplikasi yang telah dibuat menerapkan sebuah pemodelan text mining dengan mengklasifikasikan komentar ke dalam sentimen negatif (bullying dan bukan bullying) dan sentimen positif. Pemodelan text mining yang diterapkan menggunakan metode Naïve Bayes. Dengan adanya Aplikasi Pendeteksi Cyberbullying untuk mendeteksi komentar negatif dengan menggunakan metode Naïve Bayes Classifier diharapkan dapat membantu pengguna instagram dalam mendeteksi dan menghapus komentar negatif. Hasil pengujian confussion matrix menunjukkan nilai akurasi sebesar 98,5\%, nilai kerusakan (error rate) sebesar $1,5 \%$, nilai presisi sebesar $96 \%$, dan nilai recall sebesar $96 \%$.

Kata kunci: Cyberbullying, Instagram, Naïve Bayes Classifier

\section{Cyberbullying Detection Application for Social Media Instagram Post Comments with Naïve Bayse Classifier Method Website Based}

\begin{abstract}
Based on a survey of data from a Social Media Marketing analyst company based in Warsaw, Poland, NapoleonCat noted that the number of Instagram users in Indonesia in 2019 reached 61,610,000. Instagram allows users to share moments through photos and videos. Instagram also has a feature for commenting on posts. However, these features can have both positive and negative impacts on society. One of the negative effects is cyberbullying. In fact, Instagram social media cannot filter negative sentiment comments that contain elements of cyberbullying. The impact of cyberbullying can lead to severe depression and suicide. Therefore, the cyberbullying detection application on Instagram is a solution for finding comments that contain negative words or sentences. The application that has been made applies a text mining modeling by classifying comments into negative sentiments (bullying and not bullying) and positive sentiments. The applied text mining modeling uses the Naïve Bayes method. With the Cyberbullying Detection Application to detect negative comments using the Naïve Bayes Classifier method, it is hoped that it can help Instagram users detect and delete negative comments. The results of the Confusion matrix test showed an accuracy value of $98.5 \%$, an error rate of $1.5 \%$, a precision value of $96 \%$, and a recall value of $96 \%$.
\end{abstract}




\section{Pendahuluan}

Di era teknologi saat ini, perkembangan teknologi informasi dan komunikasi sangatlah pesat. Hal ini dibuktikan dengan mudahnya dalam mengakses internet. Salah satu fenomena dari perkembangan teknologi informasi dan komunikasi adalah penggunaan internet sebagai media komunikasi.

Berdasarkan survei data Asosiasi Penyelenggara Jasa Internet Indonesia (APJII) terakhir di tahun 2018, pengguna internet di Indonesia mencapai 171,17 juta. Dari segmen umur, ternyata remaja dari usia 15-19 tahun mempunyai penetrasi paling tinggi hingga mencapai $91 \%$. Para remaja mengakses internet untuk memperoleh informasi, menambah pengetahuan, dan memanfaatkan internet sebagai media komunikasi dan media menambah teman baru dengan menggunakan media sosial [1].

Salah satu media sosial yang sangat populer saat ini adalah Instagram. Berdasarkan survey data perusahaan analis Sosial Media Marketing yang berbasis di Warsawa, Polandia, NapoleonCat mencatat jumlah pengguna Instagram di Indonesia tahun 2019 mencapai 61.610.000 juta atau setara dengan $35,9 \%$ dari pengguna internet di Indonesia, bahkan jumlah pengguna Instagram meningkat setiap tahunnya[2].

Instagram memungkinkan penggunanya untuk berbagi momen lewat foto dan video. Momen yang dibagikan biasa disebut postingan. Bukan hanya untuk berbagi, Instagram juga memiliki fitur untuk mengomentari postingan. Namun dengan adanya fitur tersebut dapat memberikan dampak yang positif dan negatif bagi masyarakat. Salah satu dampak negatifnya adalah Cyberbullying.

Cyberbullying merupakan kejadian manakala seseorang diejek, dihina, diintimidasi, dan dipermalukan oleh orang lain melalui internet, teknologi digital, atau telepon seluler. Cyberbullying yang dimaksud dalam hal ini mencakup komentar sentimen negatif yang mengandung unsur cyberbullying pada postingan tertentu dengan pesan personal tak bersahabat di media sosial instagram. Cyberbullying dapat berdampak pada mental korbannya, cenderung mengalami depresi sedang hingga berat, emosional, dan merasa tidak percaya diri yang dapat mengakibatkan depresi, percobaan pembunuhan bahkan bunuh diri [3].

Jika pendeteksi tindakan cyberbullying dilakukan secara konvensional maka akan memakan waktu yang lama karena harus mendeteksi ribuan komentar. Maka diperlukan suatu aplikasi yang dapat membantu masyarakat dalam mendeteksi tidakan cyberbullying tersebut secara massal.

Berdasarkan penjabaran di atas solusi dari permasalahan tersebut adalah dibuatnya suatu "Aplikasi Pendeteksi Cyberbullying Terhadap Komentar Postingan Media Sosial Instagram Dengan Metode Naive Bayes Classifier". Instagram dipilih karena sosial media ini adalah salah satu sosial media teraktif di Indonesia. Instagram juga dipilih karena instgram menyediakan Application Programming Interface (API) yang digunakan untuk mengambil data pengguna dan komentar [4].

Pada penulisan skripsi ini, peneliti menggali informasi dari penelitian-penelitian sebelumnya sebagai bahan perbandingan, baik mengenai metode yang digunakan dan kesimpulan yang ada. Selain itu, peneliti juga menggali dari buku, skripsi dan jurnal dalam rangka mendapatkan suatu informasi yang ada sebelumnya tentang teori tentang judul yang digunakan untuk memperoleh landasan teori ilmiah.

Penelitian tentang Aplikasi Pendeteksi Cyberbullying menggunakan metode Naive Bayes Classifier sebelumnya sudah pernah dilakukan oleh peneliti lain, salah satunya adalah Restio Afrinza pada tahun 2019, yang merupakan seorang mahasiswa Program Studi Ilmu Komputasi Fakultas Informatika Universitas Telkom Bandung dengan judul "Deteksi Cyberbullying Pada Twitter Menggunakan Naive Bayes Classifier". Peneliti menggunakan metode Naive Bayes Classifier untuk menentukan mengklasifikasikan data yang dikumpulkan dari tweets pada twitter menjadi dua berupa sentimen positif dan sentimen negatif. Aplikasi yang dibuat oleh peneliti berupa Aplikasi Pendeteksi Cyberbullying berbasis website yang dibuat menggunakan bahasa pemrograman PHP, HTML, CSS, dan MySQL. Penggunaan aplikasi tersebut terbatas untuk 9750 data latih dan 3250 data uji. Untuk menentukan akurasi dari algoritma Naive Bayes, yaitu menggunakan metode confusion matrix. Hasil penelitian yang dibuat oleh peneliti menghasilkan sistem yang dapat mengklasifikasikan sentimen dengan hasil pengujian untuk 3250 tweet data uji yaitu accuracy $82,12 \%$, precision $85,28 \%$, recall $95,22 \%$ dan error rate $15,70 \%$ [5].

Penelitian lain yang serupa dilakukan oleh Ika Yunida Anggraini pada tahun 2018, peneliti merupakan seorang mahasiswi Program Studi Sistem Informasi Fakultas Teknik Universitas Nusantara PGRI Kediri dengan judul "Pemodelan Deteksi Cyberbullying Pada Jejaring Sosial Twitter". Peneliti membuat sebuah pemodelan text mining dengan mengklasifikasikan tweets pada jejaring sosial Twitter kedalam kelas bullying dan kelas bukan bullying menggunakan metode Naive Bayes Classifier. Peneliti menggunakan 5 tahap dalam proses preprocessing yaitu replace tokens, transform case, tokenization, filter stopwords, dan n-grams. Untuk memvalidasi model peneliti melakukan proses 10 -Fold Validation dan untuk menguji kinerja model pada data real maka peneliti melakukan proses testing. Pemodelan tersebut pada proses validasi menggunakan 10-Fold Validation memiliki hasil accuracy sebesar $82,50 \%$ dan standard deviation kurang lebih 5,12\%. Sementara pada proses testing model bekerja dengan baik dengan accuracy sebesar $90 \%$. Berdasarkan hasil penelitian yang dilakukan peneliti, maka dapat ditarik kesimpulan bahwa deteksi cyber bullying pada jejaring sosial Twitter dapat dilakukan dengan beberapa teknik. Pertama, data berupa tweets dikumpulkan melalui proses data crawling. Kedua, dilakukan proses seleksi data, cleaning data dan preprocessing untuk mempersiapakan data pada proses 
mining. Ketiga, dilakukan klasifikasi menggunakan Nä̈ve Bayes Classifier [6].

Selain itu ada juga penelitian serupa yang berhubungan dengan Aplikasi Pendeteksi Cyberbullying menggunakan logika Naive Bayes Classifier. Penelitian ini dilakukan oleh Alfa Saleh pada tahun 2014 yang merupakan seorang mahasiswa Teknik Informatika STMIK Potensi Utama Medan dengan judul "Klasifikasi Metode Naive Bayes Dalam Data Mining Untuk Menentukan Konsentrasi Siswa (Studi Kasus di MAS PAB 2 Medan)". Peneliti menerapkan metode Naive Bayes Classifier untuk menentukan konsentrasi siswa berdasarkan data latih dengan kriteria jenis kelamin, nilai mata pelajaran, angket, rekomendasi dan konsentrasi. Hasil penelitian yang dibuat oleh peneliti untuk mengetahui konsentrasi siswa dengan metode Naive Bayes menunjukkan keakuratan hasil klasifikasi yang diperoleh sesuai dengan data yang diujikan sebesar $90,8333 \%$, dimana data 120 siswa yang diuji, terdapat sebanyak 109 siswa data berhasil diklasifikasikan dan diprediksi dengan benar. Berdasarkan hasil penelitian yang dilakukan peneliti, maka dapat ditarik kesimpulan bahwa metode Naive Bayes Classifier dapat membantu proses data mining untuk menentukan konsentrasi siswa. Pertama, data berupa tweets dikumpulkan melalui proses data crawling. Metode Naive Bayes Classifier memanfaatkan data latih untuk menghasilkan probabilitas setiap kriteria untuk class yang berbeda, sehingga nilainilai probabilitas dari kriteria tersebut dapat dioptimalkan untuk memprediksi konsentrasi siswa [7].

Berdasarkan beberapa penelitian tersebut, penelitian yang akan dilalukan yaitu berfokus pada aplikasi pendeteksi komentar cyberbullying di postingan media sosial Instagram. Tujuan dari penelitian ini adalah menghasilkan suatu aplikasi yang dapat mendeteksi komentar negatif yang mengandung unsur cyberbullying.

Penelitian ini menjadi penting karena dapat menjadi solusi dari permasalahan Cyberbullying Terhadap Komentar Postingan Media Sosial Instagram. Berdasarkan latarbelakang yang diuraikan maka perlu dibangun sebuah Aplikasi Pendeteksi Cyberbullying Terhadap Komentar Postingan Media Sosial Instagram Dengan Metode Naive Bayes Classifier ini diharapkan dapat mempermudah dalam mendeteksi dan menghapus komentar cyberbullying.

\section{Metodologi Penelitian}

\section{A. Metode Penelitian}

Metode atau langkah-langkah penelitian yang akan dilakukan adalah sebagai berikut:

\section{Analisis Kebutuhan}

Pada tahapan ini dilakukan analisis mengenai kebutuhan fungsional dan kebutuhan non fungsional aplikasi.

2. Pengumpulan Data

Pengumpulan data dilakukan dengan teknik studi literatur dan web scrapping.

3. Perancangan Aplikasi
Perancangan aplikasi terdiri dari perancangan arsitektur aplikasi, perancangan DFD (Data Flow Diagram), perancangan basis data, flowchart aplikasi, preprocessing, perhitungan naïve bayes classifier dan perancangan antarmuka aplikasi.

4. Pembuatan Aplikasi

Pembuatan aplikasi merupakan tahap pembuatan aplikasi berdasarkan hasil perancangan aplikasi.

5. Pengujian Aplikasi

Pengujian dilakukan untuk mengetahui kelayakan aplikasi yang telah dibuat terhadap tujuan pembuatan aplikasi. Pengujian menggunakan metode confussion matrix untuk menguji fungsionalitas aplikasi.

6. Analisis Hasil Pengujian

Analisis terhadap hasil pengujian dilakukan untuk mengetahui karakteristik aplikasi yang telah dikembangkan.

7. Penarikan Kesimpulan

Kesimpulan dirumuskan berdasarkan pengujian yang telah dilakukan.

. Langkah Penelitian ini dapat di lihat pada gambar 1.

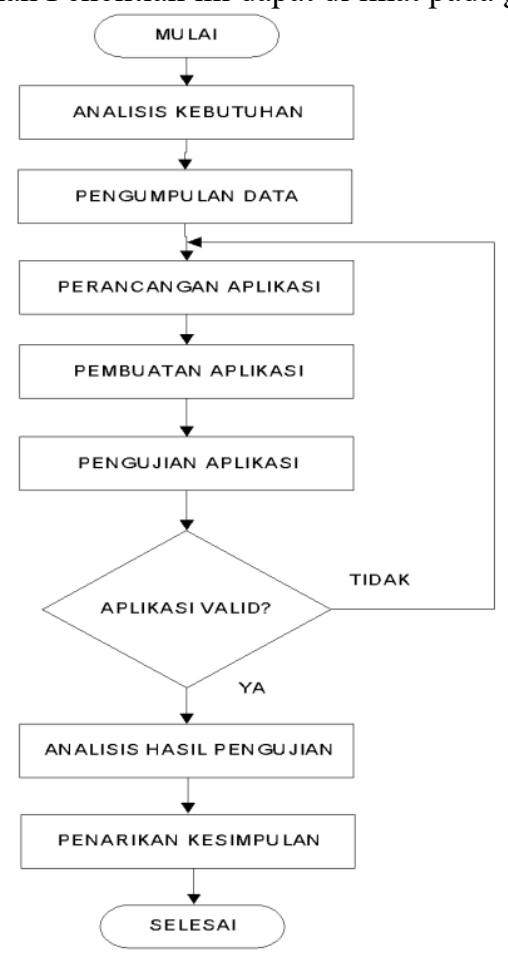

Gambar 1.Diagram Alir Penelitian

\section{B. Nä̈ve Bayes Classifier}

Naïve Bayes Classifier merupakan suatu algoritma yang digunakan untuk mencari nilai probabilitas tertinggi untuk mengklasifikasikan data uji pada kategori yang paling tepat. Pada penelitian ini yang menjadi data uji adalah dokumen komentar postingan sosial media Instagram. Ada dua tingkat klasifikasi terhadap komentar postingan media sosial Instagram. Klasifikasi pertama, aplikasi mengklasifikasikan kriteria sentimen positif dan negatif. Jika klasifikasi pertama menunjukkan komentar 
adalah sentimen positif, maka tidak dilanjutkan untuk ke tingkat selanjutnya. Jika klasifikasi pertama menunjukkan komentar adalah sentimen negatif, maka dilanjutkan ke tingkat klasifikasi yang kedua, yaitu klasifikasi kelas bullying dan kelas bukan bullying [8]. Kelebihan dari Naïve Bayes adalah proses klasifikasi data dapat disesuaikan dengan sifat dan kebutuhan masing-masing [9].

Dalam algoritma Nä̈ve Bayes Classifier setiap dokumen akan direpresentasikan dengan pasangan atribut "x1, x2, x3, ... xn" dimana x1 adalah kata pertama, x2 adalah kata kedua dan seterusnya. Kemudian himpunan kategori komentar direpresentasikan dengan atribut $\mathrm{V}$. Pada saat klasifikasi, algoritma akan mencari nilai probabilitas kemunculan tertinggi dari semua kategori yang diujikan. Nilai probabilitas ini akan direpresentasikan dengan atribut VMAP, maka persamaan 2.1 adalah sebagai berikut :

$$
\mathrm{V}_{\mathrm{MAP}}=V_{j} \in V \quad \frac{P\left(x_{1}, x_{2}, x_{3}, \ldots x_{n} \mid V_{j}\right) P\left(V_{j}\right)}{P\left(x_{1}, x_{2}, x_{3}, \ldots x_{n}\right)}
$$

\section{Alat Bantu Perancangan Sistem}

Perancangan dilakukan dengan membuat konsep perancangan berupa rancangan awal aplikasi yaitu dengan Flowchart, Data Flow Diagram, dan Entity Relationship Diagram.

Flowchart adalah suatu bagan dengan simbol-simbol tertentu yang menggambarkan urutan proses secara mendetail dan hubungan antara suatu proses (instruksi) dengan proses lainnya dalam suatu program. [10].

Data flow diagram (DFD) adalah diagram yang menggunakan notasi simbol untuk menggambarkan arus data sistem [11].

Entity Relationship Diagram (ERD) adalah model teknik pendekatan yang menyatakan atau menggambarkan hubungan suatu model [12].

\section{D. $M y S Q L$}

MySQL adalah relational database management system (RDBMS) yang diditribusikan secara gratis dibawah licensi GPL (General Public License) [13]. MySQL sebenarnya merupakan turunan salah satu konsep utama dalam database sejak lama yaitu SQL (Structured Query Language). SQL adalah sebuah konsep pengoperasian database terutama untuk pemilihan/seleksi dan pemasukan data yng memungkinkan pengoperasian data dikerjakan dengan mudah dan secara otomatis.

Kehandalan suatu sistem basis data dapat diketahui dari cara kerja optimizer-nya dalam melakukan proses perintah-perintah SQL, yang dibuat oleh user maupun program-program aplikasinya. Sebagai database server, MySQL dapat dikatakan lebih unggul dibandingkan database server lainnya dalam query data. Hal ini terbukti untuk query yang dilakukan oleh single user, kecepatan query My SQL dapat sepuluh kali lebih cepat dari
PostgreSQL dan lima kali lebih cepat dibandingkan Interbase.

\section{E. Pengujian Pengujian Confussion Matrix}

Confusion matrix merupakan alat yang digunakan untuk menganalisa seberapa baik klasifikasi mengenali tuple dari kelas yang berbeda. True Positif dan True Negatif memberikan informasi ketika klasifikasi benar, sedangkan False Positif dan False Negatif memberikan informasi ketika klasifikasi salah [14]. Confusion matrix memuat informasi tentang klasifikasi yang diprediksi dengan benar oleh sebuah sistem klasifikasi [15].

Tahapan pengujian menggunakan confusion matrix dilakukan dengan beberapa parameter pengujian yakni accuracy, recall, precision, dan error rate. Kemudian hasil dari pengujian tersebut selanjutnya akan dilakukan analisis lebih lanjut untuk dapat ditarik kesimpulan [16].

TABEL I

PENGUJIAN CONFUSSION MATRIX

\begin{tabular}{|l|l|l|}
\hline $\begin{array}{l}\text { Klasifikasi } \\
\text { / Aktual }\end{array}$ & YA & TIDAK \\
\hline YA & TP & FN \\
\hline TIDAK & FP & TN \\
\hline
\end{tabular}

Tabel I. menunjukkan bahwa hasil klasifikasi benar sesuai dengan keputusan sistem (TP) dan Klasifikasi salah menurut sistem (FP). Sedangkan dokumen yang tidak termasuk dalam hasil klasifikasi kategori, adakalanya memang bukan anggota dari kategori itu (TN) dan adakalanya ternyata seharusnya menjadi anggota kategori tersebut $(\mathrm{FN})$.

Keempat parameter pada Tabel I. digunakan untuk menghitung 4 metode evaluasi yakni :

1. Accuracy

Merupakan perbandingan jumlah seluruh dokumen relevan dengan jumlah seluruh dokumen. Accuracy memiliki rumusan sebagai berikut :

1. Recall

$$
\text { Accuracy }=(T P+T N)
$$

Merupakan perbandingan jumlah dokumen yang relevan terkenali dengan jumlah seluruh dokumen relevan. Recall memiliki rumusan sebagai berikut :

$$
\text { Recall }=T P /(T P+F P)
$$

\section{Precision}

Merupakan perbandingan jumlah dokumen yang relevan terkenali dengan jumlah dokumen yang terkenali. Precision memiliki persamaan sebagai berikut :

$$
\text { Precission }=T P /(T P+F N)
$$

\section{Error Rate}

Merupakan nilai benar (1) dikurangi dengan nilai akurasi. Error rate memiliki persamaan yang mewakili seluruh kinerja sistem yang merupakan penggabungan nilai Recall dan Presicion. Error rate memiliki persamaan sebagai berikut :

$$
\text { Error rate }=1 \text { - Accuracy }
$$




\begin{tabular}{|l|c|c|}
\hline \multirow{2}{*}{ Nilai Asli } & \multicolumn{2}{|c|}{ Nilai Prediksi } \\
\cline { 2 - 3 } & True Bullying & $\begin{array}{l}\text { True Bukan } \\
\text { Bullying }\end{array}$ \\
\hline $\begin{array}{l}\text { Prediksi } \\
\text { Bullying }\end{array}$ & 70 & 0 \\
\hline $\begin{array}{l}\text { Prediksi } \\
\text { Bukan } \\
\text { Bullying }\end{array}$ & 5 & 25 \\
\hline
\end{tabular}

Nilai accuracy, recall, dan precision dinyatakan dalam persen. Semakin tinggi persentase ketiga nilai tersebut menunjukan semakin baik kinerja sistem klasifikasi teks otomatis. Sedangkan untuk error rate berlaku sebaliknya.

\section{F. Perancangan Arsitektur Sistem}

Arsitektur sistem merupakan cara yang digunakan untuk menggambarkan sistem secara umum, gambaran arsitektur tersebut dibangun berdasarkan informasi yang didapatkan dari analisis kebutuhan dan pengumpulan data. Komponen aplikasi terdiri dari data dan informasi atau proses, seperti pada Gambar 2, aplikasi yang akan dibangun ini berbasis web, yang dapat diakses oleh pengguna instagram dan admin. Pada aplikasi yang dibuat, admin memanajemen data yang ada pada aplikasi melalui web browser, kemudian dikirim ke server dan disimpan dalam database. Pengguna atau user membuka aplikasi melalui web browser dan memilih postingan yang akan dideteksi atau diklasifikasi cyberbullying.

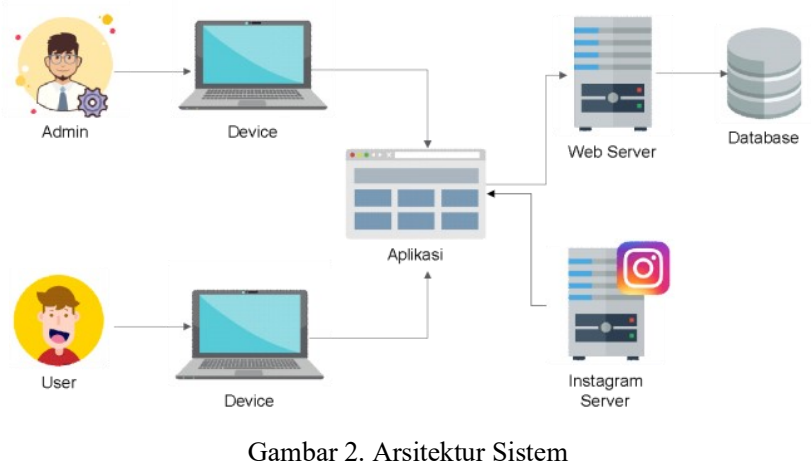

\section{HASIL DAN PENGUJIAN}

Pada bagian ini dibahas mengenai perhitungan dan pengujian dari aplikasi pendeteksi cyberbullying terhadap komentar instagram dengan metode Naïve Bayes Classifier. Pengujian perhitungan dilakukan menggunakan pengujian confussion matrix. Pengujian confussion matrix dilakukan untuk memeriksa apakah aplikasi telah berjalan dengan baik dan benar sesuai dengan tujuan yang diharapkan. Confussion matrix akan diujikan pada 100 data sampel komentar, yang terdiri dari 70 komentar bullying dan 30 komentar bukan bullying diuji dengan membandingkan dengan data latih. Hasil pengujian confussion matrix disajikan dalam sebuah tabel seperti pada Tabel II.

\section{TABEL II}

HASIL PENGUJIAN CONSFUSSION MATRIX

\section{A. Hasil Penelitian}

Perancangan yang telah dilakukan terdiri dari perancangan arsitektur sistem, diagram alir sistem, dan basis data. Perancangan tersebut menghasilkan sebuah Aplikasi Pendeteksi Cyberbullying terhadap komentar postingan media sosial Instagram. Antarmuka dari sistem diantaranya adalah antarmuka admin dan user.

\section{B. Antarmuka Login}

Halaman ini menampilkan form login. Pengguna atau admin akan mengisi kolom username, password, dan kemudian klik tombol sumbit.. Tampilan halaman login tahunan dapat dilihat pada Gambar 3

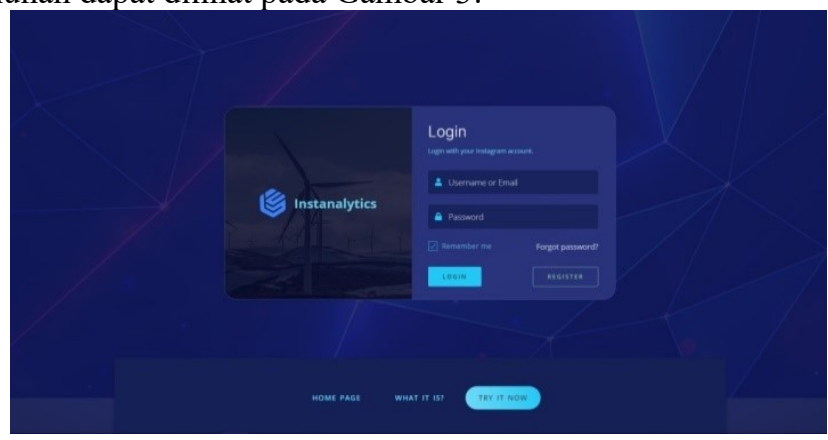

Gambar 3. Tampilan Antarmuka Login

\section{Antarmuka Admin}

Halaman beranda admin merupakan halaman yang berisi informasi cuaca, waktu, tanggal, jumlah korpus dan menu-menu yang terdiri dari menu manajemen korpus, menu pencarian, menu temukan, dan menu logout atau keluar. Tampilan lokasi beranda admin dapat dilihat pada Gambar 4.

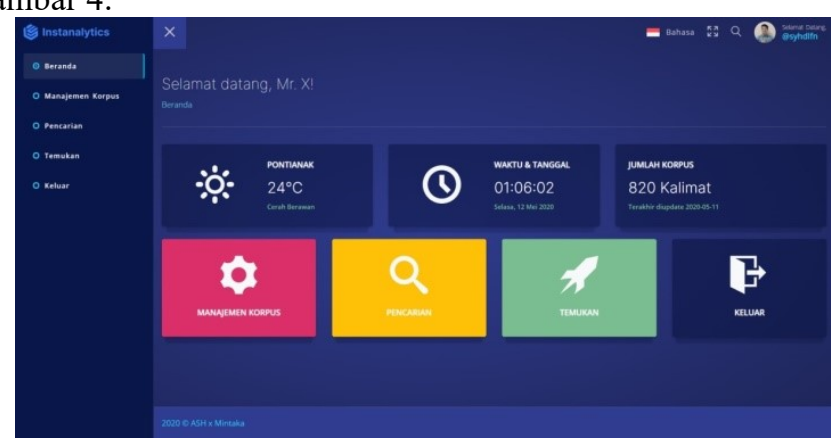

Gambar 4. Tampilan Antarmuka Admin

\section{Antarmuka Manajemen Korpus}

Halaman manajemen korpus merupakan halaman yang digunakan oleh admin untuk mengolah data korpus. Pada manajemen korpus admin dapat melakukan tambah, ubah dan hapus data korpus. Data korpus merupakan data yang menjadi acuan aplikasi untuk mendeteksi komentar 
cyberbullying. Data korpus berisi kumpulan kalimat yang sudah dilabeli kelasnya yang terdiri dari posittif, negatif, bullying, dan bukan bullying. Halaman manajemen korpus dapat dilihat pada Gambar 5.

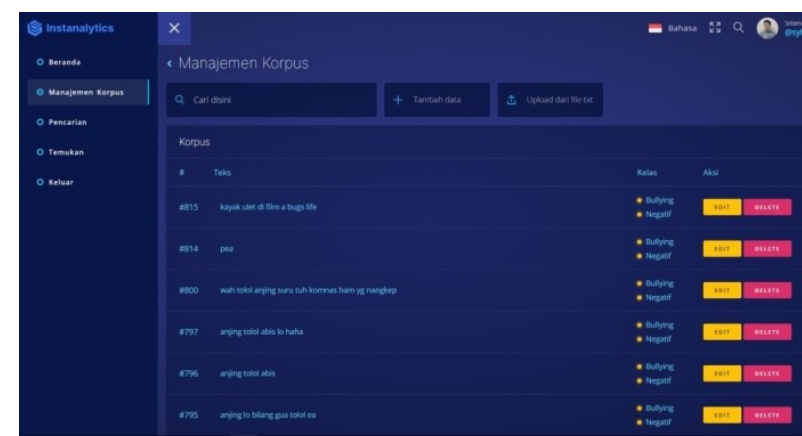

Gambar 5. Tampilan Antarmuka Manajemen Korpus

\section{E. Antarmuka Input Data Korpus}

Tampilan tambah data korpus menampilkan form yang berisi kolom isi kalimat, label kelas kalimat, dan tombol simpan. Tampilan tambah data korpus dapat dilihat pada Gambar 6.

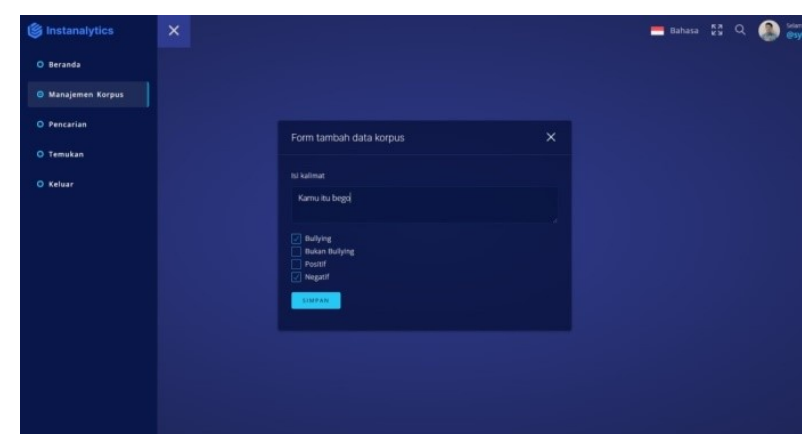

Gambar 6. Antarmuka Halaman Input Data Korpus

\section{F. Antarmuka Hasil Analisis Komentar}

Halaman ini menampilkan postingan instagram yang sedang dianalisis cyberbullying komentarnya. Halaman ini juga menampilkan isi komentar beserta hasil analisisnya berupa hasil klasifikasi menggunakan metode Naïve Bayes Classifier. Tampilan halaman hasil analisis komentar dapat dilihat pada Gambar 7.

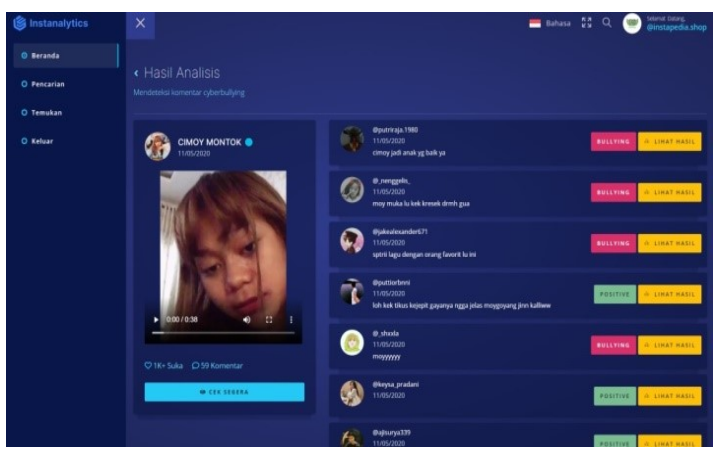

Gambar 7. Tampilan Antarmuka Hasil Analisis Komentar

\section{G. Pengujian}

Pada penelitian dilakukan dua jenis pengujian yaitu pengujian black box dan pengujian confussion matrix.

1. Pengujian Black Box

Black Box pada perangkat lunak dilakukan untuk menguji kesesuaian antara masukan dengan hasil yang ditampilkan pada aplikasi. Pengujian ini berfokus pada spesifikasi fungsional dari software, menguji kondisi input program berdasarkan apa yang dilihat, hanya fokus terhadap fungsionalitas dan output. Pengujian ini perlu dilakukan untuk melihat respon yang diberikan oleh aplikasi saat melakukan proses input data.

a) Pengujian Login

Pengujian input data dilakukan pada halaman login. Input data yang diuji adalah saat memasukkan username dan password. Lihat Tabel III.

TABEL III

PENGUJIAN HASIL UJI INPUT LOGIN

\begin{tabular}{|c|l|l|l|}
\hline \multicolumn{2}{|c|}{$\begin{array}{l}\text { Skenario } \\
\text { Pengujian }\end{array}$} & \multicolumn{1}{c|}{$\begin{array}{c}\text { Hasil } \\
\text { Uji }\end{array}$} & \multicolumn{1}{c|}{$\begin{array}{c}\text { Hasil Yang } \\
\text { Diharapkan } \\
\text { (Keterangan) }\end{array}$} \\
\hline 1 & $\begin{array}{l}\text { Input data } \\
\text { kosong }\end{array}$ & Tidak Berhasil & $\begin{array}{l}\text { Sistem akan menolak } \\
\text { untuk diproses, dan } \\
\text { menampilkan pesan } \\
\text { kesalahan: “All fields } \\
\text { is required!"” }\end{array}$ \\
\hline 2 & $\begin{array}{l}\text { Input data } \\
\text { salah satu } \\
\text { kosong }\end{array}$ & Tidak Berhasil & $\begin{array}{l}\text { Sistem akan menolak } \\
\text { untuk diproses, dan } \\
\text { menampilkan pesan } \\
\text { kesalahan: "All fields } \\
\text { is required!"” }\end{array}$ \\
\hline 3 & $\begin{array}{l}\text { Input semua } \\
\text { data diisi }\end{array}$ & Berhasil & $\begin{array}{l}\text { Berhasil login dan } \\
\text { masuk ke aplikasi }\end{array}$ \\
\hline 4 & $\begin{array}{l}\text { Input } \\
\text { username \& } \\
\text { password } \\
\text { tidak benar }\end{array}$ & Tidak Berhasil & $\begin{array}{l}\text { Sistem akan menolak } \\
\text { untuk diproses, dan } \\
\text { menampilkan pesan } \\
\text { kesalahan: "User } \\
\text { credentials are } \\
\text { wrong!" }\end{array}$ \\
\hline
\end{tabular}

b) Pengujian Hapus Komentar Cyberbullying

Pengujian berikut dilakukan pada halaman hasil analisis dalam fungsi hapus komentar cyberbullying. Fungsi ini hanya dapat dijalankan jika postingan yang dianalisis merupakan postingan milik pengguna itu sendiri. Lihat Tabel IV.

TABEL IV

PENGUJIAN HASIL UJI HAPUS KOMENTAR CYBERBULLYING

\section{\begin{tabular}{|l|l|l|} 
Skenario & Hasil & Hasil Yang Diharapkan \\
\hline
\end{tabular}}




\begin{tabular}{|c|c|c|c|}
\hline \multicolumn{2}{|c|}{ Pengujian } & Uji & (Keterangan) \\
\hline 1 & $\begin{array}{l}\text { Input data } \\
\text { kosong }\end{array}$ & Tidak Berhasil & $\begin{array}{l}\text { Sistem akan menolak } \\
\text { untuk diproses, dan } \\
\text { menampilkan pesan } \\
\text { kesalahan: } \\
\text { comments } \\
\text { selected!" }\end{array}$ \\
\hline 2 & $\begin{array}{l}\text { Input semua } \\
\text { data diisi }\end{array}$ & Berhasil & $\begin{array}{lr}\text { Berhasil menghapus } \\
\text { komentar } \\
\text { menampilkan pesan: } \\
\text { "Success } \\
\text { comments!" }\end{array}$ \\
\hline
\end{tabular}

c) Pengujian Input Data Korpus

Pengujian input data dilakukan pada halaman tambah data korpus. Input data yang diuji adalah saat memasukkan kelas dan isi kalimat. Lihat Tabel V.

TABEL V

PENGUJIAN HASIL UJI INPUT DATA KORPUS

\begin{tabular}{|c|l|l|l|}
\hline \multicolumn{2}{|c|}{$\begin{array}{l}\text { Skenario } \\
\text { Pengujian }\end{array}$} & \multicolumn{1}{c|}{$\begin{array}{c}\text { Hasil } \\
\text { Uji }\end{array}$} & $\begin{array}{l}\text { Hasil Yang Diharapkan } \\
\text { (Keterangan) }\end{array}$ \\
\hline 1 & $\begin{array}{l}\text { Input data } \\
\text { kosong }\end{array}$ & Tidak Berhasil & $\begin{array}{l}\text { Sistem akan menolak } \\
\text { untuk diproses, dan } \\
\text { menampilkan pesan } \\
\text { kesalahan: "Failed } \\
\text { Insert Data!" }\end{array}$ \\
\hline 2 & $\begin{array}{l}\text { Input data } \\
\text { salah satu } \\
\text { kosong }\end{array}$ & Tidak Berhasil & $\begin{array}{l}\text { Sistem akan menolak } \\
\text { untuk diproses, dan } \\
\text { menampilkan pesan } \\
\text { kesalahan: "Failed } \\
\text { Insert Data!" }\end{array}$ \\
\hline 3 & $\begin{array}{l}\text { Input semua } \\
\text { data diisi }\end{array}$ & Berhasil & $\begin{array}{l}\text { Berhasil menambah } \\
\text { data korpus }\end{array}$ \\
\hline
\end{tabular}

\section{Pengujian Confussion Matrix}

Pengujian confussion matrix dilakukan untuk memeriksa apakah aplikasi telah berjalan dengan baik dan benar sesuai dengan tujuan yang diharapkan. Pengujian berikut dilakukan pada sutau postingan yang diposting oleh akun dengan username@cimoyluv. Dari hasil deteksi melalui aplikasi didapatkan 90 data komentar yang sudah diketahui klasifikasi kelasnya. Dari 90 data komentar, terdapat 21 komentar bullying dan 69 komentar bukan bullying. Hasil klasifikasi data komentar diuji melalui aplikasi dengan membandingkan dengan data latih secara otomatis menggunakan metode Nä̈ve Bayes Classifier. Hasil klasifikasi data komentar yang dilakukan dengan aplikasi akan dibandingkan dengan hasil klasifikasi yang seharusnya. Perbandingan hasil klasifikasi data komentar tersebut dapat dilihat pada Tabel VI.
TABEL VI.

PERBANDINGAN HASIL KLASIFIKASI DATA KOMENTAR

\begin{tabular}{|c|c|c|c|}
\hline No. & Komentar & $\begin{array}{c}\text { Hasil } \\
\text { Klasifikasi } \\
\text { Aplikasi }\end{array}$ & $\begin{array}{c}\text { Hasil } \\
\text { Klasifikasi } \\
\text { Seharusnya }\end{array}$ \\
\hline 1. & $\begin{array}{l}\text { lu kaya gembel } \\
\text { najis banget }\end{array}$ & Bullying & Bullying \\
\hline 2. & $\begin{array}{l}\text { kenapa muka lu } \\
\text { uda kaya jamet } \\
\text { kuli bangunan }\end{array}$ & Bullying & Bullying \\
\hline 3. & $\begin{array}{l}\text { manis banget } \\
\text { bang }\end{array}$ & $\begin{array}{l}\text { Bukan } \\
\text { Bullying }\end{array}$ & $\begin{array}{l}\text { Bukan } \\
\text { Bullying }\end{array}$ \\
\hline 4. & $\begin{array}{l}\text { sekarang udah } \\
\text { bersihan ya bang } \\
\text { putih lagi }\end{array}$ & $\begin{array}{l}\text { Bukan } \\
\text { Bullying }\end{array}$ & $\begin{array}{l}\text { Bukan } \\
\text { Bullying }\end{array}$ \\
\hline 5. & $\begin{array}{l}\text { suaranya sih udah } \\
\text { bagus tapi masih } \\
\text { perlu banyak } \\
\text { latihan lagi }\end{array}$ & $\begin{array}{l}\text { Bukan } \\
\text { Bullying }\end{array}$ & $\begin{array}{l}\text { Bukan } \\
\text { Bullying }\end{array}$ \\
\hline 6. & $\begin{array}{l}\text { glowup banget ya } \\
\text { sist aku jadi } \\
\text { makin sayang } \\
\text { bangsat }\end{array}$ & $\begin{array}{l}\text { Bukan } \\
\text { Bullying }\end{array}$ & $\begin{array}{l}\text { Bukan } \\
\text { Bullying }\end{array}$ \\
\hline 7. & $\begin{array}{l}\text { imut banget si } \\
\text { kamu gemes deh } \\
\text { liatnya }\end{array}$ & $\begin{array}{l}\text { Bukan } \\
\text { Bullying }\end{array}$ & $\begin{array}{l}\text { Bukan } \\
\text { Bullying }\end{array}$ \\
\hline 8. & $\begin{array}{l}\text { semoga anakku } \\
\text { kelak mirip lo ya } \\
\text { bang }\end{array}$ & $\begin{array}{l}\text { Bukan } \\
\text { Bullying }\end{array}$ & $\begin{array}{l}\text { Bukan } \\
\text { Bullying }\end{array}$ \\
\hline 9. & $\begin{array}{l}\text { banyak tingkah } \\
\text { banget lo }\end{array}$ & $\begin{array}{l}\text { Bukan } \\
\text { Bullying }\end{array}$ & $\begin{array}{l}\text { Bukan } \\
\text { Bullying }\end{array}$ \\
\hline 10. & $\begin{array}{l}\text { bajingan kau ya } \\
\text { bisa bisanya } \\
\text { bertingkah di } \\
\text { keadaan yang } \\
\text { seperti ini }\end{array}$ & Bullying & Bullying \\
\hline 11. & $\begin{array}{l}\text { kenapa harus ada } \\
\text { dia disamping lu } \\
\text { gaterima gua } \\
\text { muka dia kaya } \\
\text { kontol basi }\end{array}$ & Bullying & Bullying \\
\hline
\end{tabular}

Dari table Table VI. dapat disimpulkan bahwa hasil klasifikasi yang seharusnya menunjukkan 75 komentar bullying dan 125 komentar bukan bullying. Selanjutnya perbandingan hasil klasifikasi akan diujikan dengan metode confussion matrix. Hasil pengujian confussion matrix dapat dilihat pada Tabel VII.

TABEL VII

HASIL PENGUJIAN CONSFUSSION MATRIX 


\begin{tabular}{|l|c|c|}
\hline \multirow{2}{*}{ Nilai Asli } & \multicolumn{2}{|c|}{ Nilai Prediksi } \\
\cline { 2 - 3 } & True Bullying & $\begin{array}{l}\text { True Bukan } \\
\text { Bullying }\end{array}$ \\
\hline $\begin{array}{l}\text { Prediksi } \\
\text { Bullying }\end{array}$ & 75 & 3 \\
\hline $\begin{array}{l}\text { Prediksi Bukan } \\
\text { Bullying }\end{array}$ & 3 & 122 \\
\hline
\end{tabular}

Berdasarkan table hasil pengujian diatas, didapatkan

hasil sebagi berikut:

1. Accurary $=(\mathrm{TP}+\mathrm{TN}) / \mathrm{N}=(75+122) / 200=98,5 \%$

2. Error Rate $=1-$ Accuracy $=1-98,5 \%=1,5 \%$

3. Precision $=\mathrm{TP} /(\mathrm{TP}+\mathrm{FP})=75 /(75+3)=96 \%$

4. Recall $=\mathrm{TP} /(\mathrm{TP}+\mathrm{FN})=75 /(75+3)=96 \%$

Hasil dari proses klasifikasi komentar cyberbullying melalui aplikasi yang didapat memiliki akurasi yang sangat tinggi, yaitu 98,5\% dengan nilai rating error $1,5 \%$, nilai presisi $96 \%$ dan nilai recall $96 \%$.

\section{KESIMPULAN}

Kesimpulan yang didapatkan dari hasil metodologi penelitian, analisis sistem, perancangan dan pengujian untuk aplikasi pendeteksi cyberbullying terhadap komentar postingan media sosial instagram dengan metode naive bayes classifier membuktikan bahwa aplikasi yang telah dibuat dalam penelitian ini dapat mendeteksi dan menghapus ribuan komentar cyberbullying secara massal. Dari hasil deteksi cyberbullying melalui aplikasi terhadap 200 data komentar dari suatu postingan media sosial instagram menunjukkan bahwa terdapat 78 komentar bullying dan 122 komentar bukan bullying. Hasil deteksi tersebut kemudian diujikan menggunakan metode confussion matrix. Dari hasil pengujian confussion matrix menunjukkan bahwa perhitungan yang dilakukan oleh aplikasi memiliki nilai akurasi sebesar 98,5\%, nilai kerusakan (error rate) sebesar $1,5 \%$, nilai presisi sebesar $96 \%$, dan nilai recall sebesar 96\%. Berdasarkan hasil penelitian, diketahui bahwa kata kunci "tolol" merupakan kata dengan bobot paling tinggi yang paling sering digunakan untuk melakukan cyberbullying yaitu sebesar 13,82 \%. Pola kalimat yang berpotensi paling besar merupakan kalimat cyberbullying adalah "Subyek + kata bully", dengan subyek "lu" berpotensi paling besar digunakan untuk melakukan aktifitas cyberbullying yaitu sebesar $15,46 \%$.

\section{REFERENSI}

Asosiasi Penyelenggara Jasa Internet Indonesia [APJII]. 2014. Profil Pengguna Internet Indonesia. Jakarta : Asosiasi Penyelenggara Jasa Internet Indonesia. https://napoleoncat.com/stats/social-media-users-inindonesia/2019/12

[3] Oktaviani, Yolanda. "Perundungan dunia maya (cyberbullying) menurut undang-undang RI NO.19 Tahun 2016 tentang informasi transaksi elektronik dan hukum islam Universitas Islam Negeri Radenfatah Palembang". Palembang : Universitas Islam Negeri Radenfatah. 2017.

Pratama, Ripanti. "Analysis of Student Academic Performance and Social Media Activities by UsingData Mining Approach". Jurnal. Pontianak : Fakultas Informatika Universitas Tanjungpura. 2020

Afrinza, Restio. "Deteksi Cyber Bullying pada Twitter Menggunakan Naive Bayes Classifier. Skripsi. Bandung" : Fakultas Informatika Universitas Telkom. 2019.

[6] Anggraini, Ika Yunida. "Pemodelan Deteksi Cyberbullying Pada Jejaring Sosial Twitter. Skripsi. Kediri" : Fakultas Teknik Universitas Nusantara PGRI Kediri. 2018.

[7] Saleh, Alfa. "Klasifikasi Metode Naive Bayes Dalam Data Mining Untuk Menentukan Konsentrasi Siswa (Studi Kasus di MAS PAB 2 Medan)". Skripsi. Medan : Fakultas Teknik Informatiak Universitas STMIK Potensi Utama Medan. 2014.

[8] Feldman, R., \& Sanger. J. "Text Mining Handbook : Advanced Approaches in Analyzing Unstructured Data". New York : Cambridge University Press. 2007.

[9] Gunawan, Billy. "Sistem Analisis Sentimen pada Ulasan Produk Menggunakan Metode Naïve Bayes". Pontianak : Jurnal Edukasi dan Penelitian Informatika. 2018.

[10] M. Suyanto. "Analisis \& desain aplikasi multimedia untuk pemasaran". Yogyakarta : Penerbit Andi. 2004.

[11] S. Yuswanto. "Mengolah Database dengan SQL Server 2000". Surabaya : Prestasi Pustaka Publ. 2005.

[12] Jogiyanto, H.M. "Analisa dan Desain Sistem: Pendekatan Teori Dan Praktek Aplikasi Bisnis. Cetakan Ketiga". Yogyakarta : Andi Offset. 2005.

[13] Dwi Prasetyo, Didik.. "Tips dan Trik Kolaborasi PHP dan MySQL untuk membuat web database yang interaktif". Elex Media Komputindo : Jakarta. 2003.

[14] Han, J., Kamber, M., \& Pei, J. "Data Mining Concepts and Techniques Third Edition". Waltham : Elsevier Inc. 2011.

[15] Hamilton, Howard. (2017). Confusion Matrix.http://www2.cs.uregina.ca/ hamilton/courses/831/n otes/confusion_matrix/confusion_matrix.html, 24 Maret 2018.

[16] Juniarsih, Ripanti, Pratama. "Implementasi Naive Bayes Classifier pada Opinion Mining Berdasarkan Tweets Masyarakat Terkait Kinerja Presiden”. Jurnal. Pontianak : Fakultas Informatika Universitas Tanjungpura. 2020. 